\title{
Eating with the enemy? Mimic complex between a stingless bee and assassin bugs
}

\author{
Leopoldo Jesús Alvarez ${ }^{1,3,4}$; Fernando Zamudio ${ }^{2,3}$ \& Maria Cecilia Melo ${ }^{1,3,5}$ \\ 1 Universidad Nacional de La Plata (UNLP), Facultad de Ciencias Naturales y Museo (FCNyM), División Entomología. La Plata, Argentina. \\ 2 Universidad Nacional de Córdoba (UNC), Facultad de Ciencias Exactas, Físicas y Naturales (FCEFYN), \\ Instituto Multidisciplinario de Biología Vegetal (IMBIV), Interacciones Ecológicas y Conservación. Córdoba, Argentina. \\ ORCID: http://orcid.org/0000-0003-1204-0715. E-mail:zamufer@yahoo.com.ar \\ ${ }^{3}$ Consejo Nacional de Investigaciones Científicas y Técnicas (CONICET). \\ ${ }^{4}$ ORCID: http://orcid.org/0000-0003-4330-9617. E-mail: lalvarez@fcnym.unlp.edu.ar \\ ${ }^{5}$ ORCID: http://orcid.org/0000-0003-4612-452X. E-mail: ceciliamelo@fcnym.unlp.edu.ar (corresponding author)
}

\begin{abstract}
In this study, we record for the first time the genus Notocyrtus (Heteroptera, Reduviidae) from Argentina based on three species: Notocyrtus dorsalis (Gray), Notocyrtus dispersus Carvalho \& Costa, and Notocyrtus foveatus Stål. We also describe and illustrate a mimetic complex comprising the three Notocyrtus species and Tetragona clavipes (Fabricius) (Apidae, Meliponini), that were collected on Bahuinia forficata Link (Leguminosae: (aesalpinioideae). We include biological comments on the plant-reduvid-bee interaction and hypothesize about the functionality of the mimetic complex described.
\end{abstract}

Key-Words. Harpactorinae; Meliponini; Notocyrtus; Bauhinia; Extrafloral nectaries.

\section{INTRODUCTION}

Trophic interactions have the largest influence on community structure (Paine, 1980). Although there is ample evidence of commensalism relationships between insect-insect and insect-plant, competition for resources and/or the presence of extrafloral resources of plants and/or their hosts, promote the emergence of predators and opportunistic parasites, and the emergence of mimetic pairs (Fowler, 1992). Among the harpactorines (Reduviidae), outstanding examples of mimicry occur with some groups of Hymenoptera (GilSantana et al., 2015). Many genera of Harpactorini, such as Hiranetis Spinola, Graptocleptes Stål, and Coilopus Elkins, resemble braconid ichneumonid, and/or vespid wasps (Maldonado Capriles \& Lozada Robles, 1992; Forero \& Giraldo-Echeverry, 2015). Species of Notocyrtus Burmeister are recognized as mimetics of meliponine bees which they resemble mostly because of the inflated pronotum (Haviland, 1931; Jackson, 1973; Gil-Santana, 2008). Because some species of this genus are variable in colour, particularly in the thorax, it has been postulated that it may be a result of mimicking different meliponine bees in different localities (Jackson, 1973). Among harpactorines, three pairs of mimetics had been identified: Trigona fulviventris Guérin-Méneville, 1844 as model of Notocyrtus vesiculosus (Perty, 1834) (Jackson, 1973); Ptilotrigona lurida (Smith, 1854) as model of $N$. colombianus Carvalho \& Costa, 1992 (Gil-Santana, 2008); and Tetragonula collina (Smith, 1857) (as Trigona collina) as model of Pahabengkakia piliceps Miller, 1941 (Wattanachaiyingcharoen \& Jongjitvimol, 2007).

Stingless bees (Apidae: Meliponini) are a large and diverse group of bees of pantropical distribution (Michener, 2007, 2013) that includes approximately 400 Neotropical species (Camargo \& Pedro, 2007). All meliponine are eusocial, as they live in permanent colonies and have two castes of well differentiated females: workers and queen (Michener, 2007, 2013). This group has stablished a large number of interactions with other animals and plants due to the highly variable morphologies (size, colour, etc.), behaviours, and foraging habits (Roubik, 1989; Michener, 2007; Biesmeijer \& Slaa, 2004). During resource collection multiple antagonistic or mutualistic interactions between stingless bees and plants, and between stingless bees and other insects have been observed (Howard, 1985; Almeida-Neto et al., 2003; Leonhardt \& Blüthgen, 2009; Oda et al., 2009, 2014; Gastauer et al., 2011; Barônio et al., 2012; Alves et al., 2015).

In this study, we record for the first time the genus Notocyrtus from Argentina based on three species, and we describe and illustrate a mimetic complex comprised of Tetragona clavipes (Fabricius, 1804) as the model of Notocyrtus species. Also, we provide biological comments on the 
plant-reduvid-bee interaction and speculate about the functionality of the mimetic complex described.

\section{MATERIAL AND METHODS}

Field work was carried out in the lguazú National Park, located in the Iguazú Department, Misiones Province, Argentina between $25^{\circ} 31^{\prime} \mathrm{S}$ to $25^{\circ} 43^{\prime} \mathrm{S}$ and $54^{\circ} 08^{\prime} \mathrm{W}$ to $54^{\circ} 32^{\prime} \mathrm{W}$. At its northern area it includes the Iguazú Falls, the largest waterfalls system in the world and an UNESCO World Natural Heritage Site since 1984. The Park protects 67,720 ha of the Paraná Forest, and it is the most diverse area in Argentina with ca. 3,000 of vascular plants forming a stratified forest that harbours a diverse fauna (Chebez, 2005).

Field observations and specimens' collection were made during two inventories of wild bees carried out during 2008-2009 and 2017-2018, in the Iguazú National Park. Wild bees and reduviids were collected with entomological nets when foraging on flowers or any other substrate of the natural vegetation. Furthermore, to attract and capture male orchid bees, we used bait traps with four different scents (cineol, eugenol, vanilla extract, and methyl salicylate). These chemical compounds were diluted in ethylene glycol and placed in traps at two different heights (canopy, $12 \mathrm{~m}$; and undergrowth, $1.5 \mathrm{~m}$ ). Six sets of traps were placed along a transect of approximately $30 \mathrm{~km}$ that runs through the park. Bait traps consisted in $600 \mathrm{ml}$ plastic bottles with two lateral holes of three centimetres on the sides. Voucher specimens were deposited in the entomological collection of the Museo de La Plata, Argentina (MLP).

Material collected: Notocyrtus dispersus: 2 females, Argentina, Misiones, P.N. Iguazú, Rta. 101, sobre Bauhinia forficata, 06-XII-2017, L. Alvarez \& P.J. Ramello cols. (MLP). Notocyrtus dorsalis: 1 female, Argentina, Misiones, P.N. Iguazú, Rta. 101, 09-IV-2017, recolectada con Cineol, sitio 4, $25^{\circ} 42^{\prime} 03.0^{\prime \prime} \mathrm{S}, 54^{\circ} 12^{\prime} 14.9^{\prime \prime} \mathrm{W}$, dosel $12 \mathrm{~m}$, L. Alvarez \& M. Lucia cols. (MLP); 1 female, Argentina, same data, 23-I-2017, L. Alvarez \& P.J. Ramello cols. (MLP); 1 female, same data, 08-XII-2017, L. Alvarez \& P.J. Ramello cols. (MLP); 1 male, same data, 27-IV-2018, L. Alvarez \& D. Aquino cols. (MLP); 1 female, same data, Cineol, si-

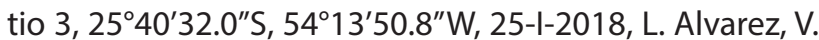
Almada \& A. Avalos cols. (MLP); 2 females, same locality, 27-IV-2018, s/ Bahuinia forficata, L. Alvarez \& D. Aquino cols. [leg.] (MLP); 2 females, same locality, 28-IV-2018, s/ Bahuinia forficata, L. Alvarez \& D. Aquino cols. (MLP). Notocyrtus foveatus: 1 female, Argentina, Misiones, P.N. Iguazú, Rta. 101, 27-IV-2018, s/ Bahuinia forficatea, L. Alvarez \& D. Aquino cols. (MLP). Tetragona clavipes: 25 workers, Argentina, Misiones, P.N. Iguazú, Rta. 101, 16-XII-2008, 20-XI-2008, 14-II-2009, Zamudio-CollesselliGómez de Oliveira cols. (MLP); 2 workers, same locality, 28-IX-2016, L. Alvarez, P.J. Ramello \& M. Lucia cols. (MLP); 1 worker, same locality, 07-09-IV-2017, L. Alvarez \& M. Lucia cols. (MLP); 3 workers, same locality, 28-IV-2018, s/ Bahuinia forficatea, L. Alvarez \& D. Aquino cols. (MLP).

\section{RESULTS AND DISCUSSION}

In these surveys we noticed that young trees of Bahuinia forficata Link (Leguminosae: Caesalpinioideae), regularly without flowers, were frequently visited by many workers of Tetragona clavipes (Figs. 1C, 2A and 2E), and in less number by Tretagonisca and Trigona stingless bees; ants of the genus Camponotus sp., and butterflies of the genus Dynamine (Nymphalidae) (Figs. 1A and 1B). Surprisingly, we also found specimens of Notocyrtus strongly associated with Bahuinia plants and apparently mimicking Tetragona clavipes. The specimens were identified as Notocyrtus dorsalis (Gray, 1832) (Figs. 1D, 1E, 2C and 2G), Notocyrtus dispersus Carvalho \& Costa, 1992 (Figs. 2D and 2H); and Notocyrtus foveatus Stål, 1872 (Figs. 2B and 2F).

The stingless bee Tetragona clavipes has been recorded from Argentina, Bolivia, Brazil, Colombia, Guyana, Paraguay, Peru, Suriname, and Uruguay (Camargo \& Pedro, 2007), and is very common in Misiones Province. Its colonies are numerous, and the workers exhibit a very aggressive nest defensive behaviour (Zamudio \& Alvarez, 2016). Workers of this species also present an aggressive foraging behaviour, as numerous individuals aggressively defend resources (mainly flowers) from other species (Biesmeijer \& Slaa, 2004).

The three species of Notocyrtus represent new records for the Argentinean fauna. Notocyrtus dorsalis is widely distributed in South America, and has been recorded from Bolivia, Brazil, Colombia, Costa Rica, Ecuador, Guatemala, Guyana, Mexico, Panama, Paraguay, Peru, and Surinam (Stål, 1872; Walker, 1873; Lethierry \& Severin, 1896; Champion, 1898; Haviland, 1931; Wygodzinsky, 1949; Maldonado Capriles, 1990; Carvalho \& Costa, 1993; Gil-Santana \& Forero, 2009). Notocyrtus dispersus is known from Brazil and Paraguay (Carvalho \& Costa, 1992), and N. foveatus from Brazil, Colombia, Panama, Paraguay, Peru, Venezuela (Carvalho \& Costa, 1993; Gil-Santana, 2007).

Bahuinia forficata subsp. pruinosa is a tree or shrub up to $10 \mathrm{~m}$ high with branched stems and the characteristic bilobed leaves of most of the species of the genus (Fortunato, 1986). This feature gives them the common name "pata de vaca" (cow's foot), used to name several of Bahuinia species in Latin America. This species lacks spines in adult stage, but juveniles present two short aculeos or stingers around each petiole of the leaf (Figs. 1A-C and 1E) (Fortunato, 1986). Unlike true spines, aculeos are excrescences of the epidermis and underlying tissues but without vascular tissue (Font Quer, 1970). Recently, the aculeos of $B$. forficata subsp. pruinosa have been described as a new type of extrafloral nectary embedded and hidden within these structures (Gonzalez \& Marazzi, 2018). These false spines produce a drop of transparent and viscous nectar during the development of new shoots and leaves in young plants (Gonzalez \& Marazzi, 2018). Extrafloral nectaries occur in more than 100 species from angiosperm families and some ferns (Weber \& Keeler, 2013). They are secretory structures that trigger indirect defence mechanisms in which aggres- 

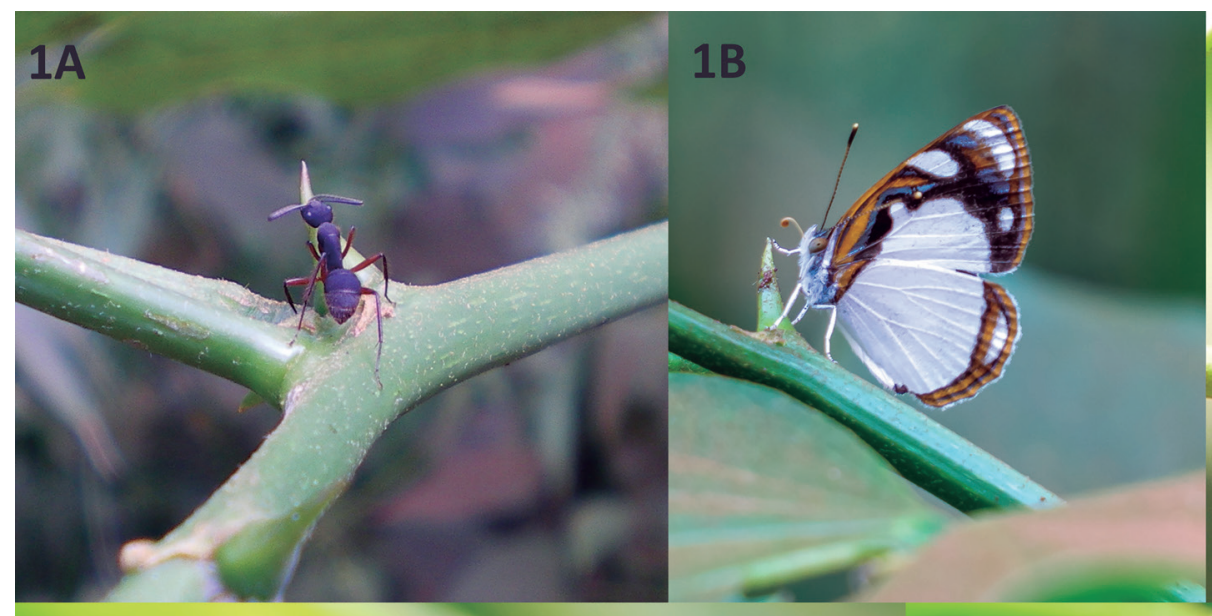

$1 C$

1D

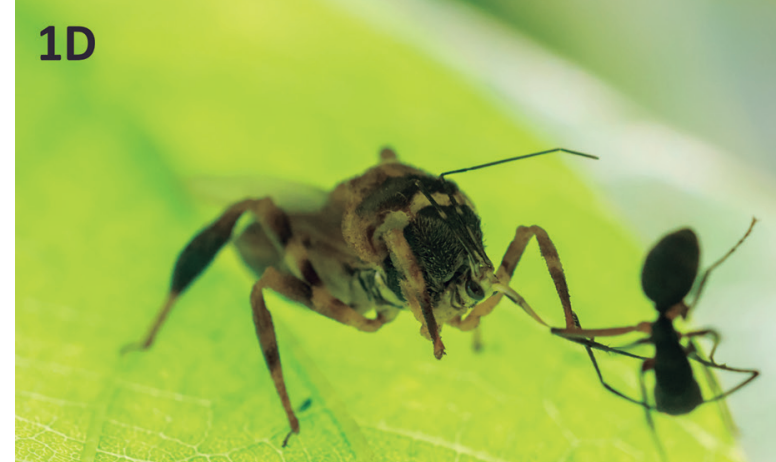

$1 \mathrm{E}$

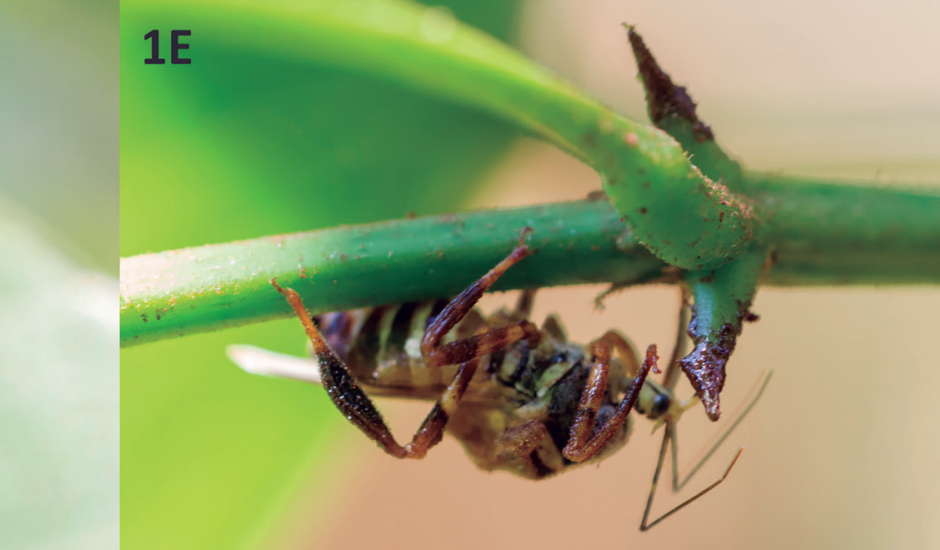

Figure 1. Diversity of visitors of extrafloral nectaries of Bauhinia forficata Link. (A) Worker of Camponotus rufipes (Fabricius) (Hymenoptera: Formicidae). (B) Dynamine coenus (Fabricius) (Lepidoptera: Nymphalidae). (C) Worker of Tetragona clavipes (Fabricius) (Hymenoptera: Apidae: Meliponini). (D) Notocyrtus dorsalis (Gray) preying an ant C. rufipes. (E) N. dorsalis feeding on extrafloral nectary.

sive ants often guard the plant in return for the carbohydrate-rich reward (Beattie, 1985; Koptur, 1992; Bronstein et al., 2006; Trager et al., 2010).

The observed Bahuinia forficata bushes were regularly "defended" by numerous ants. Camponotus rufipes (Fabricius, 1775) was the most abundant species (Fig. 1A), while C. sericeiventris (Guérin-Méneville, 1838) was less frequent. We also observe the presence of other visitors of the extrafloral nectaries as butterflies and bees: Dynamine athemon (Linnaeus, 1758), D. coenus (Fabricius, 1793) (Fig. 1B), and D. artemisia (Fabricius, 1793), and the stingless bees T. clavipes, Tetragonisca fiebrigi (Schwarz, 1938) and Trigona spinipes (Fabricius, 1793); among them T. clavipes was the most common and abundant species, while $T$. fiebrigi and $T$. spinipes were found accidentally and in very low numbers.

We were able to capture four females and one male of $N$. dorsalis in the bait traps in the canopy attracted only by cineol. This method occasionally attracts other arthropods such as spiders, Coleoptera, Diptera, Hemiptera, Lepidoptera, Neuroptera, Orthoptera in addition to many Hymenoptera (mostly bees) (Campos et al., 1989; Melo, 1995; Nemésio \& Siqueira, 2011; Nemésio et al., 2013; Alvarez obs. pers.). Capture of Apiomerus mutabilis Costa Lima, Campos Seabra \& Hathaway, 1951 (Hemiptera: Reduviidae) in traps baited with cineol was also reported by Melo et al. (2017).
The fact that Notocyrtus dorsalis has been attracted and captured by baited traps is a striking fact. These synthetic scents simulate floral fragrances (Dressler, 1982), suggesting that $N$. dorsalis is attracted by fragrances from flowers or other structures like extrafloral nectaries, but the purpose of this is still unknown. Could the flowers be used as a hunting arena or are they sought to feed on the nectar? Both assumptions could be feasible. There are several reports of some species of Reduviidae, e.g., Notocyrtus gibbus (Fabricius, 1803) that certainly supplement its diet with honeydew from some hemipterans, and others with the secretion of extra-floral nectaries of plants (Haviland, 1931; Jackson, 1973; Bérenger \& PluotSigwalt, 1997; Gil-Santana \& Alves, 2011). Similarly, the use of flowers or other structures to ambush preys is a common strategy used by certain group of reduviids, the ambush bugs or Phymatinae (Miller, 1956).

As observed in other species, among the three species of Notocyrtus we found, the mimicry is achieved both by structural modifications and by similarity in coloration. The model suggested here is the worker of T. clavipes (Figs. 2A and 2E). This is a long-legged bee of $6-8 \mathrm{~mm}$ in length. The head, mesosoma, and middle and hind legs are mostly dark brown, with small yellow spots; the antennae and eyes are light brown. The metasoma is brown with conspicuous yellow bands on T1-5. The wings are hyaline but slightly tinted with 
sepia. The head is large and is slightly wider than the mesosoma in dorsal view. The distal portion of the hind tibia is broad and rounded, and the outer surface is occupied by a corbicula. The three species of Notocyrtus differ in the shape of the inflated pronotum that resembles the shape of the bees' head and mesosoma (Figs. 2B-D), and all of them show geniculate antennae and enlargement of the posterior tibiae which mimics a corbicula. About the coloration, the assassin bugs are black and yellow, with a shared pattern that resembles the meliponine bee. The anterior pronotal lobe is dark and the posterior is paler (Figs. $2 \mathrm{~F}-\mathrm{H}$ ), the hemelytra is translucent with only sclerotized veins, and the legs and abdomen show a banded pattern with the large hind tibiae darkened. We also observed that the position of the head beneath the enlarged pronotum enhance the mimetic resemblance.

The functionality of this mimetic complex is still unknown. It probably could be a case of aggressive mimicry, where an organism resembles some aspect of another organism (the model) in order to obtain prey through its deceptive resemblance (Nelson, 2014).

Meliponini bees commonly show remarkable inter and intraspecific competition during the collection of resources (Howard, 1985; Nagamitsu \& Inoue, 1997; Biesmeijer et al., 1999), therefore Notocyrtus species could be taking advantage of these relationships. One possible hypothesis is that the mimic (Notocyrtus species) "dupe" the model T. clavipes, in this case, the assassin bug could attack the stingless bee when it approaches



Figure 2. Mimic complex between Tetragona clavipes (model) and three species of Notocyrtus. (A and E) Worker of T. clavipes. (B and F) N. foveatus. (C and G) N. dorsalis. (D and H) N. dispersus. (A-D) dorsal view. (E-H) lateral view. Scale bars: $2 \mathrm{~mm}$. 
to interact with its counterfeit. However, observations made by Gil-Santana (2008) over N. fungosus Stål, 1859 showed that this species is not interested in Meliponini bees, but actively fed on nematocerous Diptera offered to them. Also, we were unable to observe the attack of Notocyrtus species to its model, but we recorded the attack of $N$. dorsalis on the ant C. rufipes (Fig. 1D). In this sense, several antagonistic relationships have been documented between ants and bees (Almeida-Neto et al., 2003; Barônio et al., 2012), since the ants actively defend their food resources (Janzen, 1966). If this is the trend, species of Notocyrtus could ambush the ants that approach to repel the "false" stingless bee. In this possibility the "dupe" would not be given on the model, but on the other visitors of Bauhinia, such as the ants.

On the other hand, we also observed that at least N. dorsalis was actively feeding on the aculeos (Fig. 1E); so, it is conceivable that the resemblance to a stingless bee can be explained by competitive mimicry. This is defined as a type of mimicry that enables access to a defended resource or aids in resource defence (Rainey \& Grether, 2007). In this way, Notocyrtus species get access to the nectar from the aculeos defended by T. clavipes. If this is the situation, this mimicry has a double purpose, access to defended resources (nectaries) and obtains an advantage over potential prey. This alternative kind of food (extrafloral nectar) was previously observed for the assassin bug Atopozelus opsimus Elkins, 1954 (Harpactorinae) from of Inga vera (Fabaceae) (Guillermo-Ferreira et al., 2012).

Nevertheless, more field observations should be made to answer the many questions posed here. Is Notocyrtus feeding on T. clavipes, or it only feeds on ants that defend the extrafloral nectaries, or other visitors as well? Is Tetragona clavipes actively defending the resources from other visitors? Do the ants attack the meliponine bees or they avoid each other? The study of multiple mutualistic effects could be an approach to unveil these questions, adding factors such as the extent of overlap in rewards exchanged among partners and their resulting network topologies, and other than visual signals like chemical (Afkhami et al., 2014). Ant exclusion experiments and addition of Notocyrtus can be a useful experiment to understand how each pair wise interaction influences the overall outcome among the three interacting parts (see Aranda-Rickert et al., 2017). Undoubtedly this is the tip of the iceberg of a complex system of interactions between visitor and predator insects associated with Bauhinia.

\section{ACKNOWLEDGMENTS}

L.A. wants to thank Juan P. Torretta, Mariano Lucia, Pablo Ramello, Valentin Almada, and Adán Avalos for their help during the field work. To the Administración de Parques Nacionales, Argentina (APN) and Centro de Investigaciones Ecológicas Subtropicales (CIES, APN) for their support for the development of the project NEA344. To Cristian Klimaitis for the identification of the butterflies, and Daniel A. Aquino (Museo de La Plata) for the field trip photographs. LJA, FZ, and MCM are supported by Consejo Nacional de Investigaciones Científicas y Técnicas, Argentina (CONICET).

Authors' contributions statement: LJA and FZ collected the specimens, LJA identified the bees, MCM identified the assassin bugs. LJA, FZ and MCM collaborate in the writing of the manuscript.

\section{REFERENCES}

Afkhami, M.E.; Rudgers, J.A. \& Stachowicz, J.J. 2014. Multiple mutualist effects: conflict and synergy in multispecies mutualisms. Ecology, 95(4): 833-844.

Almeida-Neto, M.; Izzo, T.J.; Raimundo, R.L.G. \& Rossa-Feres, D.C. 2003. Reciprocal interference between ants and stingless bees attending the honeydew-producing homopteran Aetalion reticulatum (Homoptera: Aetalionidae). Sociobiology, 42: 369-380.

Alves, L.H.; Nogueira Pereira, S.; Prezoto, F. \& Rodrigues Cassino, P.C. 2015. Ecological Interaction Among Stingless Bees, Ants, and the Whitefly Aleurothrixus aepim (Goeldi). EntomoBrasilis, 8(2): 159-161.

Aranda-Rickert, A.; Fracchia, S.; Yela, N. \& Marazzi, B. 2017. Insights into a novel three-partner interaction between ants, coreids (Hemiptera: (oreidae) and extrafloral nectaries: implications for the study of protective mutualisms. Arthropod-Plant Interactions, 11: 525-536.

Barônio, G.J.; Vieira Pires, A.C. \& Aoki, C. 2012. Trigona branneri (Hymenoptera: Apidae) as a collector of Honeydew from Aethalion reticulatum (Hemiptera: Aethalionidae) on Bauhinia forficata (Fabaceae: (aesalpinoideae) in a Brazilian Savanna. Sociobiology, 59(2): 407-414.

Beattie, A.J. 1985. The Evolutionary Ecology of Ant-Plant Mutualisms. Cambridge University Press.

Bérenger, J.M. \& Pluot-Sigwalt, D. 1997. Relations privilégiées de certains Heteroptera Reduviidae prédateurs avec les végétaux. Premier casconnu d'un Harpactorinae phytophage. Comptes rendus de l'Académie des Sciences, Sciences de la Vie, Life Sciences, 320: 1007-1012.

Biesmeijer, J.C. \& Slaa, E.J. 2004. Information flow and organization of stingless bee foraging. Apidologie, 35: 143-157. DOI

Biesmeijer, J.C.; Richter, J.A.P.; Smeets, M.A.J.P. \& Sommeijer, M.J. 1999. Niche differentiation in nectar-collecting stingless bees: the influence of morphology, floral choice and interference competition. Ecological Entomology, 24: 380-388. D0I

Bronstein, J.L.; Alarcón, R. \& Geber, M. 2006. The evolution of plant-insect mutualisms. The New Phytologist, 172: 412-428.

Camargo, J.M.F. \& Pedro, S.R.M. 2007. Meliponini Lepeletier, 1836. In: Moure, J.S.; Urban, D. \& Melo, G.A.R. (Eds.). Catalogue of bees (Hymenoptera, Apoidea) in the Neotropical Region. Curitiba, Sociedade Brasileira de Entomologia. p. 272-578.

Campos, L.A.O.; Silveira, F.A.; Oliveira, M.L.; Abrantes, C.V.M.; Morato, E.F. \& Melo, G.A.R. 1989. Utilização de armadilhas para a captura de machos de Euglossini (Hymenoptera, Apoidea). Revista Brasileira de Zoologia, 6: 621-626.

Carvalho, J.C.M. \& Costa, L.A.A. 1992. Descriptions of new species of Notocyrtus Burmeister, 1835 (Hemiptera-Heteroptera, Reduviidae, Harpactorinae). Anais da Academia Brasileira de Ciências, 64(1): 71-78.

Carvalho, J.C.M. \& Costa, L.A.A. 1993. Revision of the known species of Notocyrtus Burmeister, 1835 (Hemiptera-Heteroptera, Reduviidae; Harpactorinae). Revista Brasileira de Biologia, 53(3): 365-384.

Champion, G.C. 1898. Biologia Centrali-americana: Insecta. Rhynchota. Hemiptera-Heteroptera. London, Goodman \& Salvin. v. 2. 
Chebez, J.C. 2005. Guía de las reservas naturales de la Argentina. Nordeste. Buenos Aires, Editorial Albatros. v. 3.

Dressler, R.L. 1982. Biology of the orchid bees (Euglossini). Annual Review of Ecology and Systematics, 13: 373-394.

Font Quer, P. 1970. Diccionario de Botánica. 3. reimpresión. Barcelona, Labor.

Forero, D. \& Giraldo-Echeverry, N. 2015. First record of the assassin bug genus Coilopus Elkins, 1969 (Hemiptera: Heteroptera: Reduviidae) from Colombia. Check List, 11(3): 1634. D0I

Fortunato, R.H. 1986. Revisión del género Bauhinia (Cercideae, Caesalpinioideae, Fabaceae) para la Argentina. Darwiniana, 27: 527-557.

Fowler, H.G. 1992. Aethalionidae: functional equivalents of extrafloral nectaries in Bauhinia (Cesalpinionidea). Anales de Biología, Murcia, 18(7): 155-159.

Gastauer, M.; Campos, L.A.O. \& Wittmann, D. 2011. Handling sticky resin by stingless bees (Hymenoptera, Apidae). Revista Brasileira de Entomología, 55(2): 234-240. DOI

Gil-Santana, H.R. 2007. New records of Reduviidae (Hemiptera: Heteroptera) from Brazil. Zootaxa, 1390: 59-68.

Gil-Santana, H.R. 2008. New records, and nomenclatural and biological notes on Reduviidae (Hemiptera: Heteroptera) from Bolivia and Brazil. Zootaxa, 1785: 43-53.

Gil-Santana, H.R. \& Alves, R.J.V. 2011. Association between Zelus versicolor (Herrich-Schäffer) (Hemiptera, Reduviidae, Harpactorinae) and Bidens rubifolia Kunth (Asterales, Asteraceae). EntomoBrasilis, 4(1): 30-32.

Gil-Santana, H.R. \& Forero, D. 2009. A new species of Notocyrtus, a new synonym of Coilopus, and new records and notes on other Harpactorini (Hemiptera: Heteroptera: Reduviidae: Harpactorinae) from South America. Zootaxa, 2148: 55-67.

Gil-Santana, H.R.; Forero, D. \& Weirauch, C. 2015. Assassin Bugs (Reduviidae Excluding Triatominae). In: Panizzi, A.R. \& Grazia, J. (Eds.). True Bugs (Heteroptera) of the Neotropics. Dordrecht, Springer Science+Business Media. p. 307-351 (Entomology in Focus 2)

Gonzalez, A.M. \& Marazzi, B. 2018. Extrafloral nectaries in Fabaceae: filling gaps in structural and anatomical diversity in the family. Botanical Journal of the Linnean Society, 187: 26-45.

Gray, G.R. 1832. [New genera and species] In: Griffith, E. The Animal Kingdom arranged in accordance to its organization by the Baron Cuvier. Paris. v. 15, part 2.

Guillermo-Ferreira, R.; Cardoso-Leite, R. \& Gandolfo, R. 2012. First observation of alternative food usage (extrafloral nectar) by the assassin bug Atopozelus opsimus (Hemiptera, Reduviidae). Revista Brasileira de Entomologia, 56(4): 489-491. D0I

Haviland, M.D. 1931. The Reduviidae of Kartabo (Bartica District). Zoologica, New York, 7(1): 129-154.

Howard, J.J. 1985. Observations on Resin Collecting by Six Interacting Species of Stingless Bees (Apidae: Meliponinae). Journal of the Kansas Entomological Society, 58(2): 337-345.

Jackson, J.F. 1973. Mimicry of Trigona Bees by a Reduviid (Hemiptera) from British Honduras. Florida Entomologist, 56(3): 200-202.

Janzen, D.H. 1966. Coevolution of mutualism between Ants and Acacias in Central America. Evolution, 20(3): 249-265.

Koptur, S. 1992. Extrafloral nectary-mediated interactions between insects and plants. In: Bernays, E. (Ed.). Insect-plant interactions, Boca Raton, Boca Raton Press. v. 4, p. 81-129.

Leonhardt, S.D. \& Blüthgen, N. 2009. A Sticky Affair: Resin Collection by Bornean Stingless Bees. Biotropica, 41(6): 730-736.

Lethierry, L.F. \& Severin, G. 1896. Catalogue général des hémiptères. Hétéroptères. Bruxelles, F. Hayez. v. 2.

Maldonado Capriles, J. 1990. Systematic catalogue of the Reduviidae of the world (Insecta: Heteroptera). Mayaguez, University of Puerto Ric0. 694p.
Maldonado Capriles, J. \& Lozada Robles, PW. 1992. Key to the group of Neotropical wasp-mimetic harpactorine genera and the description of a new species (Hemiptera: Reduviidae). Proceedings of the Entomological Society of Washington, 94(1): 162-165.

Melo, G.A.R. 1995. Fragrance gathering by Euglossa males in flowers of Ternstroemia dentate (Theaceae) (Hymenoptera: Apidae: Euglossinae). Entomologia Generalis, 19: 281-283.

Melo, M.C.; Dellapé, G.; Olivera, L.; Varela, P.S.; Montemayor, S.I. \& Dellapé, P.M. 2017. Biodiversity of true bugs from Iguazú National Park, Argentina. Check List, 13(5): 479-511. D0I

Michener, C.D. 2007.The Bees of the world. 2. ed. Baltimore, Johns Hopkins University Press.

Michener, C.D. 2013. The meliponini. In: Vit, P; Pedro, S.R.M. \& Roubik, D.W. (Eds.). Pot-honey: a legacy of stingless bees. Berlin, Springe. p. 3-17.

Miller, N.C.E. 1956. The Biology of the Heteroptera. London, Leonard Hill (Books) Limited. 162p.

Nagamitsu, T. \& Inoue, T. 1997. Aggressive foraging of social bees as a mechanism of floral resource partitioning in an Asian tropical rainforest. Oecologia, 110: 432-439.

Nelson, X.J. 2014. Evolutionary implications of deception in mimicry and masquerade. Current Zoology, 60(1): 6-15.

Nemésio, A. \& Siqueira, E.L. 2011. Acanthopus excellens Schrottky, 1902 (Hymenoptera: Apidae: Ericrocidini) attracted to eugenol in southeastern Brazil. North-Western Journal of Zoology, 7: 164-166.

Nemésio, A.; Seixas, D.P. \& Rasmussen, C. 2013. Trigona pallens (Fabricius, 1798) (Hymenoptera: Apidae) strongly attracted to vanillin in northeastern Peru. Brazilian Journal of Biology, 73(3): 677-678. D01

Oda, F.H.; Aoki, C.; Oda, T.M.; Da Silva, R.A. \& Felismino, M.F. 2009. Interação entre abelha Trigona hyalinata (Lepeletier, 1836) (Hymenoptera: Apidae) e Aethalion reticulatum Linnaeus, 1767 (Hemiptera: Aethalionidae) em Clitoria fairchildiana Howard (Papilionoideae) EntomoBrasilis, 2: 58-60.

Oda, F.H.; Oliveira, A.F. \& Aoki, C. 2014. Oxytrigona tataira (Smith) (Hymenoptera: Apidae: Meliponini) as a collector of honey dew from Erechtia carinata (Funkhouser) (Hemiptera: Membracidae) on Caryocar brasiliense Cambessédes (Malpighiales: Caryocaraceae) in the Brazilian Savanna. Sociobiology, 61(4): 566-569.

Paine, R.T. 1980. Food Webs: Linkage, Interaction Strength and Community Infrastructure. Journal of Animal Ecology, 49(3): 666-685.

Rainey, M.M. \& Grether, G.F. 2007. Competitive mimicry: synthesis of a neglected class of mimetic relationships. Ecology, 88(10): 2440-2448.

Roubik, D.W. 1989. Ecology and natural history of tropical bees. New York, Cambridge University Press.

Stål, C. 1872. Enumeratio Reduviidarum Americae. Konglinga VetenskapsAkedemiens Handlingar, 10(4): 66-128.

Trager, M.D.; Bhotika, S.; Hostetler, J.A.; Andrade, G.V.; Rodriguez-Cabal, M.A.; McKeon, C.S.; Osenberg, C.W. \& Bolker, B.M. 2010. Benefits for plants in ant-plant protective mutualisms: a meta-analysis. PLoS One, 5(12): e14308.

Walker, F. 1873. Catalogue of the specimens of Hemiptera Heteroptera in the collection of the British Museum. London, Trustees of the British Museum. v. 8.

Wattanachaiyingcharoen, W. \& Jongjitvimol, T. 2007. First Record of the Predator, Pahabengkakia piliceps Miller, 1941 (Reduviidae, Harpactorinae) in the Stingless Bee, Trigona collina Smith, 1857 (Apidae, Meliponinae) in Thailand. The Natural History Journal of Chulalongkorn University, 7(1): 71-74.

Weber, M.G. \& Keeler, K.H. 2013. The phylogenetic distribution of extrafloral nectaries in plants. Annals of Botany, 111: 1251-1261.

Wygodzinsky, P. 1949. Elenco sistemático de lo reduviformes americanos. Instituto Medicina Regional Tucumán. 102p.

Zamudio, F. \& Alvarez, L.J. 2016. Abejas sin aguijón de Misiones: Guía etnotaxonómica. Córdoba, Ar. Editorial de la UNC. 